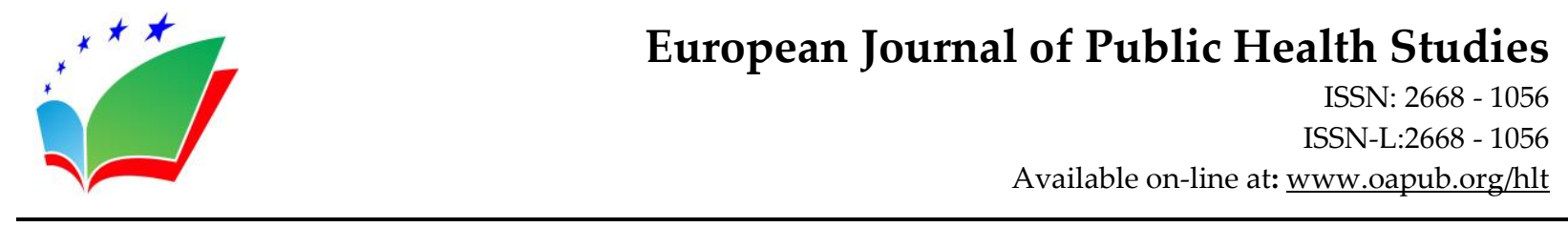

DOI: $10.46827 /$ ejphs.v4i1.90

Volume 4 | Issue 1 | 2021

\title{
SOCIAL AWARENESS ABOUT HYGENIC FOOD FOR MOTHERS \& THEIR CHILDREN
}

\author{
Taherun Nesa Subarna, \\ Nuruddin Ahmed Masud ${ }^{i}$ \\ Master of Education Management, \\ School of Teacher Education, \\ Huzhou University, \\ China
}

\begin{abstract}
:
In many low-income developing regions, socioeconomic, climate and demographic, food hygienic factors have been linked to around half of the disease-related deaths that occur each year in the slum area. The purpose of the study is to be aware of hygienic food for mother and their children and find out the government awareness program in the Purba Bania Khamar slums area of the Khulna city of Bangladesh. A community-based survey was carried out in this study. Factors associated with malnutrition, sanitation, water supply, shelter, and food security were assessed using SPSS. The results indicate that the food of mothers and children in a slum place is healthy and safe. Especially healthy foods are recommended from a variety of sources.
\end{abstract}

Keywords: children's food security, mother's food security, living conditions, health conditions, food hygiene

\section{Introduction}

Foods are adulterated by using various harmful chemicals and toxic artificial colors, on the one hand, and rotten perishables turned into poisonous foods are stored, sold, and served to consumers in an unhygienic atmosphere, on the other. The food hygiene contamination and food adulteration situation of Bangladesh is a serious public health concern. WHO estimates that globally foodborne and waterborne diarrheal diseases taken together kill about 2.2 million people annually, of the 1.9 million are children. However, in Bangladesh dependable assessment of the public health impact due to food contamination is not available due to the absence of a regular monitoring system. Limited data from the ICDDR, B indicates 501 hospital visits per day for treatment of diarrhea that were attributable to food and waterborne causes. The general scenario on food contamination demonstrates a widespread non-compliance with hygienic practice in

i Correspondence: email nuruddinahmedmasud@gmail.com, suborna631@gmail.com 
food handling among the food producers and the food traders such as street food traders. The chronic effect of such events as cancer, kidney disorders, and birth defects is unlikely to observe in the short term because the manifestation of the disease only occurs after long-term, low-level exposure. Food contamination and consumers' exposure to food hazards have major implications on food security and consumers' health in Bangladesh. Low level of awareness and weakness in existing Food laws and regulations are also contributing to aggravating the country's food safety situation.

\subsection{Statement of the Problem}

Bangladesh is a poor small country, but its population is very big. Man cannot live without food. They devoted their time and energy to the development of the cottage industry and culture. But we now suffer greatly from the shortage of foodstuffs every year. The causes of the food problem in Bangladesh are many. Our total land area is 14 million hectares or 35 million acres. We are too many (about 110 million) to live on this small land. Sixty percent of our total land is occupied by cultivable land. On average, each person has only 0-37 acres of cultivable land. Most of our lands are plowed in the traditional way. It is also true that we should not depend on other countries for food stuffs. We must bring every inch of our idle land under plow. Then land must be examined, classified, and plotted out. Labor should be given proper training in the scientific methods of cultivation. More and more areas of land should be brought under the irrigation system. Our land has the potential to yield much more product. If our manpower is appropriately utilized, we will soon be able to double food production. In this way, we can figure out the difficulty.

\subsection{Purpose of the Study}

\subsubsection{Broad Purpose}

The general purpose of the study is to be awareness of hygienic food for mother and their children and find out the government awareness program in Purba Bania Khamar slums area of the Khulna City of Bangladesh.

\subsubsection{Specific Purpose}

Overall, the topic and view authors' mind some specific purposes of the study have been very important to identify as follows:

1) To determine the hygienic food security status for mother and their children of the study area;

2) To conclude more government awareness campaign for hygienic food in study area;

3) To analyse the hygienic and healthy food conservation and resource system for mother and their children of the study area. 


\subsection{Research Questions}

1) What is food security among children and their mother?

2) How to improve hygienic food for children and their mothers in a slum area?

\section{Literature Review}

Social awareness is an important role in our society and everyday human life. According to different journals and articles published in the context of Bangladesh by scholars, we may get a detailed and clear view of social awareness about hygienic food for mother and their children.

According to Noman (2013), in Bangladesh, most of the foodstuffs are manufactured or processed, are unsafe for consumption, or adulterated to varying degrees. Food is adulterated by using various harmful chemical and toxic artificial colures, on the one hand, and rotten perishables turned into poisonous foods are stored, sold, and served to consumers in an unhygienic atmosphere, on the other. The unhygienic and unsafe treatment of food is seriously affecting public health by causing numerous chronic and non-chronic diseases.

Rashad Faridi et al. (2010) explains that the determinants of the household food security situation in Bangladesh. Different household characteristics seem to be strongly correlated with food security indicators which might be helpful in identifying foodinsecure households. Regression result shows that food security indicators are also highly sensitive to rice price changes. Comparison of different occupational groups was also studied with the finding that wage earners, both daily wage and salary wage earners, are worse off in terms of food security status compared to self-employed both in agriculture and non-agriculture sectors.

According to Mizanur (1993), the study examined a host of socio-economic and demographic factors (including their interactions) that determine infant/child mortality of married women at the different parity levels in Bangladesh. A multivariate analysis of 1975-76 Bangladesh fertility Survey (BFS) data shows that age is a significant positive determinant, and education of the wife is a significant positive determinant, and education of the wife is a significant negative determinant of infant/child mortality for low-parity ( 3 and below child's births) women.

Mosfequr (2015) said that the association between unintended pregnancy and maternal and child health has been well documented. Methods: data from the 2011 Bangladesh Demographic and Health Survey on 6,506 last-born, singleton children younger than five were using to investigate the relationship between pregnancy intenseness and the prevalence of stunting, wasting, and underweight during early childhood. Results: Substantial proportions of children were stunted (40\%), wasted $(16 \%)$, and underweight $(35 \%)$ at the time of the survey. Mothers reported that the time of conception, $14 \%$ of their index pregnancies had been unwanted and $16 \%$ had been mistimed. Compared with children whose conception had been intended, those whose conception had been unwanted were more likely to be stunted (46\% vs. $39 \%$ ), wasted 
(19\% vs. 15\%), or underweight (43\% vs. 33\%). Conclusion: Maternal pregnancy intentions are associated with child stunting, wasting, and underweight.

Abbas Bhuiya et al. (1991) is according to the study whether the positive effect of mothers' education on child survival is similar for boys and girls in Matlab, Bangladesh. The five independent variables included in the analysis are the sex of children, mother's education, and mother's age at the time of birth, household economic condition, and health program block. Hazard analysis shows that the positive effect of a mother's education on child survival is different for boys and girls. For boys, a change in mother's education from no schooling to 1-5 years resulted in reducing the predicted risk of death by $45 \%$, while for the girls the reduction came to only $7 \%$. Similarly, a change in mother's education from no schooling to six or more years of schooling resulted in a reduction of risk of $70 \%$ for boys, while for girls it was only $32 \%$.

Abbas and Kim (1995) explain that the nature of feeding, home-remedy practices, and consultation with health care providers during illnesses of children in Mat lab, a rural sub-district of Bangladesh, were studied. The type of treatment was dependent on the nature of the illness. The use-rate of ORT was low. Breastfeeding discontinued for $16 \%$ of the episodes; the reduction was the highest for fever with cough, followed by fever and diarrhea.

Pradip K. Muhuri (1995) suggested that the study the extent to which differences in child mortality linked to mother's education are affected by health intervention programs. The Matlab research area in Bangladesh, the site of the study, exhibits variations in the composition of services within the intervention area, the presence of a comparison group, and a time series of accurate data since the 1960s. Differences in child mortality linked to maternal schooling were sharply diminished in the "intensive" blocks of the Matlab intervention area, moderately reduced in the no intensive blocks, and remained largely in the comparison area.

Sharifa (1983) said that during the sixties overall infant mortality rate of Bangladesh was largely static. It increased considerably in the early seventies following the liberation war of 1971 and the countrywide famine of 1974. A mortality differential by residence, however, reveals that unchanged mortality situation during the sixties prevailed only in a rural area of Bangladesh and urban mortality had been able to achieve noteworthy improvements at that time.

According to Omar (2010), Bangladesh has made great strides in improving the health of its population, much more than a country at its level of development can be expected to do. Serious problems remain in reducing child malnutrition and maternal mortality in particular; nonetheless, the aggregative results achieved in the last three decades are quite impressive. These include persistent inequities in access to healthcare (including gender inequity, and inequity along with the poor versus non-poor divide), lack of meaningful participation of citizens in the running of the health system.

Margot Wilson (1999) said the study provides an in-depth analysis of the decisionmaking processes of abandoning mothers and families. The data were collected from a shelter for abandoned women and children located in Dhaka, Bangladesh, and reflect the experiences of extremely poor women and children. Quazi Shahabuddin (2010) explains 
a large number of the people in Bangladesh are deprived of basic economic and social rights. Hence, poverty in Bangladesh, as elsewhere, is synonymous with hunger and malnutrition.

According to Khan, Ahmed, Yunus, Rahman, Samar, Marie \& Wahed (2010), Arsenic contamination of tube well water is a major public health problem in Bangladesh. In recent years arsenic and cadmium were measures in foods from Mat lab, a rural area in Bangladesh, that is extensively affected by arsenic and the economy is agriculturebased. Washing rice with water before cooking reduced the concentration of arsenic in raw rice by $13-15 \%$. Rice, when cooked with excess water, shows an important reduction in arsenic attention compared to cooking without water $(\mathrm{p}<0.001)$. In contrast, the concentration of cadmium did not decrease in cooked rice after discarding water. Cooked rice with discarded water had a significantly lower concentration of arsenic compared to raw rice $(p=0.002)$. Raw rice had a higher concentration of arsenic compared to raw vegetables $(\mathrm{p}<0.001)$; however, no such difference was found for cadmium. Compared to raw vegetables (e.g. arum), the concentration of arsenic increased significantly $(p=0.024)$ when cooked with arsenic-contaminated water. The results suggest that arsenic and cadmium have entered the food-chain of Bangladesh, and the cooking practices influence the concentration of arsenic but not of cadmium in cooked food. Mahabub Hossain (1990), Bangladesh is one of the most seriously affected country by natural disasters, being chronically prone to floods, droughts, and cyclones.

R. K. Talukder (2005), Bangladesh's food security and self-sufficiency status have been examined using both time-series and cross-section data. The aggregate and per capita food availability in the country improved over the past years, resulting from increased domestic production and improved food management. However, about $40 \%$ of people were consuming food below the absolute poverty line food intake. The analysis showed that in relation to the standard nutritional norm of food intake, Bangladesh virtually remained a surplus producer of food grains from the year 2005-06.

Paul Dorosh et al. (1995), over the past 25 years, Bangladesh's targeted food programs have varied substantially in the commodities distributed, seasons of operation, and targeting mechanisms. This paper attempts to generalize from this broad programming experience by using a seasonal multi-market model to analyze the consequences of existing and hypothetical program designs. Wheat supply injections and continued targeting of female-headed households - that offer potential gains in program efficiency, target group incomes, and calorie consumption of the poor.

De La Luz Alvarez (1987), we carried out pretest and post-test sampling on several families from the slums area who are relocated to a new housing development which has running water. Pretest sampling was performed on 52 families with children under 7 years of age, and post-testing included 45 of these original families. The same variables regarding hygiene habits were studied during data collection at both sites. Results show that the families lived before in typical slum conditions. The adequate conditions of the new house modified the use of water for washing greens and vegetables $(p<.001)$, and the washing of hands after touching something dirty $(p<.001)$, improving as well 
hygienic habits during food handling $(\mathrm{p}<.001)$ and in general $(\mathrm{p}<.05)$. All these changes occurred without any specific educational program between both periods of study.

According to Mahtab \& Kamal (1993), the rate at which the population of Bangladesh is increasing, and the present level of technology, make it impossible to produce enough food for its population in the future. Population pressure has already begun to affect the environment and agricultural sustainability. Because of the intensive land use and biomass shortage, cultivated soils are now being depleted of essential nutrients and organic matter. Barnett, Azad, Barua, Mridha, Abrar, Rego, Khan, Flatman, \& Costello (2006) said, the aim of the study was to examine the prevalence of maternal and newborn care practices among women reporting a birth in the previous year in three districts in different divisions of Bangladesh. In 2003, 6,785 women, who had delivered a newborn infant in the previous year, across three districts in Bangladesh were interviewed. Overall, less than half of the women received any antenatal care, and 11\% received a minimum of four check-ups.

Mostafa, Hoque, Nahar, \& Evans (2004) said that nitrogen is the most limiting element in Bangladesh soils and urea is the fertilizer commonly used for supplying it. Bradyrhizobium/Rhizobium inoculants were tried as a source of $\mathrm{N}$ nutrition for grain legumes in a number of field experiments. The inoculants markedly increased nodule number, nodule mass, shoot weight, and yield of the crops compared to inoculate control and urea-N treatments. For soybean (Glycine max), inoculation increased yield 113\% over the control and $49 \%$ over the urea treatment. For groundnut (Arachis hypogaea), the increases were 36\% and 11\%; for lentil (Lens culinaris), 30\% and 13\%; and for mungbean (Vignaradiata), 47\% and 7\%. The local inoculants strains were suitable for dependable inoculants production. The Inoculants technology can be used as a promising and cheap substitute of urea for growing food legume crops in Bangladesh.

Held \& Phillips (1990), the study examined the role of food and water contamination in a health impact evaluation of a water and sanitation intervention project. Although lower diarrhea rates were found in the improved area no consistent difference in food and water contamination was observed between areas. The focus of interventions should therefore be on changing behaviors to improve overall hygiene.

Razzaque, Khondker, Bazlul, Mujeri \& Mustafa (1997) the study estimates demand elasticity's using the food characteristics demand system for eight different occupational groups in Bangladesh. The methodology, based on the assumption that every food item contributes to overall energy and variety in the diet which together maximizes the utility from energy, variety, and tastes of individual foods suggests that with an increase in incomes, most occupational groups are likely to increase their consumption for non-cereal food items.

K. A. S. Murshid (1986) said that food policy planning in Bangladesh has consistently ignored the problem of output fluctuations, despite the fact that this has led to considerable dislocation to overall economic performance. A necessary first step, therefore, is to attempt an assessment of the broad magnitudes involved, as well as their dispersion and trend. 
Above all journals regarding "Social awareness of hygienic food for mother and their children" I would like to say that we have to do firstly awareness among human beings. On this issue whatever awareness programmed like seminar, conference, TV live programmed, advertisement and so on circulate this awareness message all over the world. On this issue, we have to differentiate the merits and demerits of hygienic food and non-hygienic food. So that the people can understand its essence in their practical life. Materials and methods most important materials needed to use for completing a research paper. Different types of methods conducted for complete successful research. This chapter discusses instruments to use to formulating research problems and relevant factors of research. It also describes instruments used for data collection information related content. Validity and reliability will be present procedures for data collections and analysis will be discussed.

\section{Material and Methods}

Very important to describe the study because of which study was carried out. This chapter detail description of the Khulna districts slum areas study was conducted. The Khulna district's slum areas geographical location, topography \& climate, and full environment were described.

\subsection{Selection of the Study Area}

The most successful of a study based on their choice of the study area. Selection of study area, which will show the imagination of area and they represent the entire nation picture for the present study Purba Bania Khamar slums area of Khulna city is select.

\subsection{Reconnaissance Method}

A reconnaissance survey has conducted to get preliminary knowledge about the study also; it is helpful to prepare the questionnaire.

\subsection{Data Collection Methods}

The whole research study makes based on their primary source of the data. Secondary data is supporting or helping data of primary data. Due to the limit, some data was collected from reference materials, official records, and other secondary sources.

The primary source of data is the children. Most of them are school-going students. Through face-to-face interview, data is collected. Here the primary source is those people who have faced food insecurity and not hygienic

Secondary data such a data, which is supplied by different NGO's data and websites Secondary information including citations, data as well as tables, picture, and graph, were also collected from different study report published in recent year with acknowledgment. 


\subsection{Determination of Sampling Technique and Sample Size}

Various limitations to possible a successful survey for the study the simple random sampling was used. The sample size for data collection from each structure obtained from the following equation cited by Kothari (2009);

$$
\mathrm{n}=\mathrm{z} 2 \mathrm{pqN} / \mathrm{e} 2(\mathrm{~N}-1)+\mathrm{z} 2 \mathrm{pq}
$$

Where,

$\mathrm{n}$ = sample size $\mathrm{z} 2$ =the value of the slandered variant at a given confidence level,

$\mathrm{p}=$ Sample proportion,

$\mathrm{q}=1-\mathrm{p}$,

$\mathrm{e}=$ Acceptance effort,

$\mathrm{N}=$ households size of the strata.

\subsection{Draft Questionnaire Preparation Pre-testing and Finalization of the Question}

To check the reliability with actual field conditions, the questionnaire had done pretest in the field before going to take the final interview from the respondents. The errors of the questionnaire were corrected mistakes and failure also modified and changed and extra question were excluded to prepare a final questionnaire according to the study objectives.

\subsection{Questionnaire Survey}

The random sampling technique has supplied as a sampling procedure. Primary data has been collected mainly through a questionnaire survey in 2020. Various types of information have been collected from the local people in the slum areas of Khulna city and information has been collected through their self-observation and original information.

\subsection{Data Processing, Analysis and Interpretation}

All the primary and secondary collected data will be compiled and interpreted for processing and analysis. The data from the questionnaire grouped categorized and interpreted according to the objective as well as the indicators. Some data contain numeric and some contain narrative facts. For measurable and indicate answer was grouped in the tabular forms. All the collected data analyzed by prominent program MS Word, SPSS-16, and Excel 2007.

\section{Data Analysis}

In slums, areas peoples faced different types of problem in their life. Not only poor people and lower class people below poverty life people situated there they have faced many problem in coastal area agriculture and shrimp is the hunkering is the main income source of every family but at a time awareness about food hygiene for mother and their child is totally unreachable and damaged. 


\subsection{Age Range \& General information of the Respondents}

In slum areas, $32 \%$ of respondents are between 15 and 25 years of age. $48 \%$ of respondents are between 26 and 40 years of age and $18 \%$ are above $41 \%$.

Table 1: Age Range of the Respondent

\begin{tabular}{|l|c|c|}
\hline Age Range & Frequency & Percent \\
\hline $15-20$ & 12 & 12.0 \\
\hline $21-25$ & 22 & 22.0 \\
\hline $26-30$ & 18 & 18.0 \\
\hline $31-35$ & 14 & 14.0 \\
\hline $36-40$ & 16 & 16.0 \\
\hline $41-45$ & 10 & 10.0 \\
\hline Above 45 & 8 & 8.0 \\
\hline Total & 100 & 100.0 \\
\hline Mean $: 3.78$ & & S.D:1.81 \\
\hline
\end{tabular}

Source: Field Survey, 2020.

Khulna city slum areas family pattern such as single, joint and nuclear is also available family is responsible for maintaining nutritional and food hygienic status. Children and mother of single and nuclear family, as women maintaining her family and children are very difficult. Other side the joint family and few of some educated family's people may help to maintain their children and mothers' nutritional and food hygienic status. 55\% of the respondent's belongs to nuclear family while 33\% from extended family and other from broken single family.

\subsection{Number of Family Members of the Respondents}

Family member of the respondent, family may include a spouse, parent, brother, sister, son and daughter. Many of family extended category living with grandparents, aunt, and uncle, and cousin, nephew, nice or sibling-in-law. Member of family member basis show their identity to help us for divided their category. Number of Family Members majority $32 \%$ of the respondents had 2-3 family members, $18 \%$ had above seven family members, $28 \%$ had only $4-5$ family members, and $22 \%$ respondent had 6-7 family members.

\subsection{Numbers of Children of the Respondents}

Number of children mentions the size of the family. If number of children is too many then rearing and maintain during water logging period is so hard and it's also harmful for nation. $48 \%$ respondents had been $1-2$ children, while $6 \%$ respondent had been above 7 children.

\subsection{Education Status}

Everyone knows the education is only one way to progress him, society and their country. Slum area of Khulna city still most of the people are illiterate. Because lack of people doesn't know how to prevent health related hygienic disease, they don't aware about food hygiene. Among all respondents, the majority, approx. 14\% men and 39\% women, are still totally illiterate. 
Table 2: Age Range of the Respondents

\begin{tabular}{|l|c|c|c|c|c|}
\hline \multirow{2}{*}{ Category } & \multicolumn{2}{|c|}{ Men } & \multirow{2}{*}{ Category } & \multicolumn{2}{c|}{ Women } \\
\cline { 2 - 3 } \cline { 6 - 6 } & Frequency & Percent & & Frequency & Percent \\
\hline Illiterate & 40 & 40.0 & Illiterate & 58 & 58.0 \\
\hline Only can sign & 24 & 24.0 & Only Can sign & 22 & 22.0 \\
\hline Primary & 16 & 16 & Primary & 14 & 14.0 \\
\hline Secondary & 12 & 12 & Secondary & 4 & 4.0 \\
\hline Higher Secondary & 8 & 8.0 & & 2 & 2.0 \\
\hline Total & 100 & 100.0 & Total & 100 & 100.0 \\
\hline
\end{tabular}

Source: Field Survey, 2020.

\subsection{Socio-Economic Status}

Family's growth depends on their source of income and occupation. Most of the people in slums area working with Shims and agriculture so the people of this slum areas are able to provide better hygienic food for children and their family. Occupational status of slums areas people $26 \%$ respondent family had the income level of monthly 2001-3000 BDT in slums areas. Six percent of respondent come from upper middle class family income more than 4000BDT.

\subsection{Family Income Monthly}

Family income of respondents in the slums areas $24 \%$ respondent income less than 500BDT. 20\% of respondents' family earned 1001-2000 BDT, 16\% earned 2001-3000 BDT and only 4\%, respondent's families had income level 3001-5000 and more than 400BDT.

\subsection{Main Source of Expenditure}

The family has to meet their basic needs, but each person has different needs that the maximum $44 \%$ of the income respondents spend huge for his accommodation. $22 \%$ has been spent on food, $10 \%$ has been spent on her clothes, $8 \%$ has been spent on her farm or business, $16 \%$ has been extended for treatment and only $10 \%$ for others.

\subsection{Have any Savings for Children Education}

Many of them day by day saving small amount of money for their child education. 75\% respondents had savings for their children education and $25 \%$ of the respondents had no savings.

\subsection{Slums Areas Housing Pattern}

In slum area of the Khulna city most of the respondents had own land but some are more vulnerable because of that they choose different source for their residential. Here, $44 \%$ respondents had own homesteaded land. 


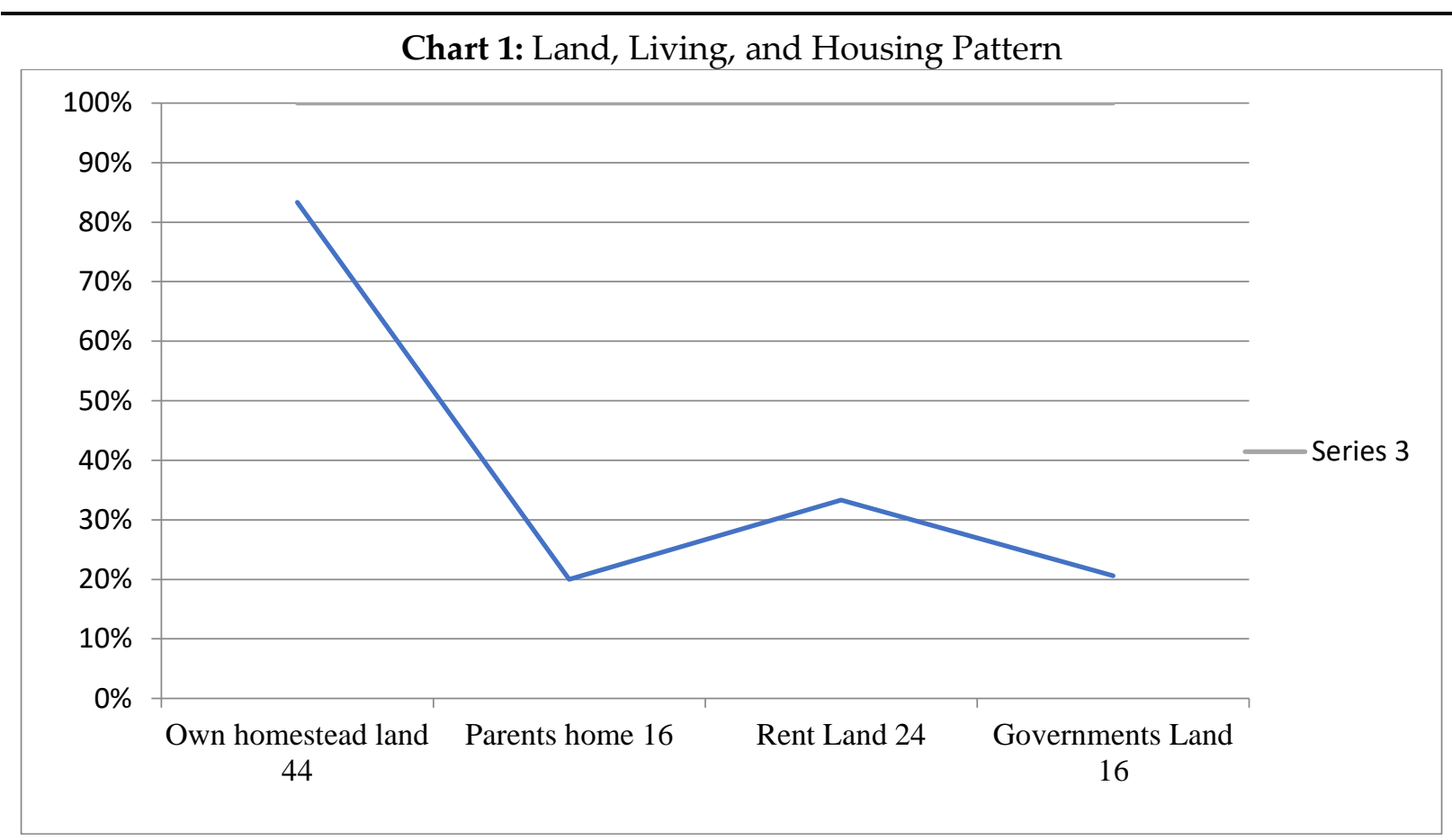

Source: Field Survey, 2020.

\subsection{Health, Treatment Facility and Mortality Rate}

In slum areas, especially in Khulna city, most of the people does not take proper treatment because they are not aware about the health and hygiene. Most of the family member low income so they have chosen low coast free treatment facility. $36 \%$ respondents choose public hospital because of the free treatment those who have financially very week they choose private sector $20 \%$ choose private clinic or hospital and homeopathic treatment, 18\% choose NGO d-quash $6 \%$ choose different treatment. $32 \%$ children took one time in a day $.46 \%$ of the respondent took 2 times meal in a day. $18 \%$ children took 3 times meal in a day and $4 \%$ took more than 3 times meal in a day.

Table 3: Types of Diseases Faced by Children

\begin{tabular}{|l|c|c|}
\hline Type of Disease & Frequency & Percent \\
\hline Diarrhea & 32 & 32.0 \\
\hline Cholera & 14 & 14.0 \\
\hline Dengue & 18 & 18.0 \\
\hline Malnutrition & 22 & 22.0 \\
\hline Skin Disease & 10 & 10.0 \\
\hline Fever & 4 & 4.0 \\
\hline Total & 100 & 100.0 \\
\hline
\end{tabular}

Source: Field Survey 2020.

$32 \%$ of the children faced diarrhea, $14 \%$ faced cholera and $22 \%$ of the children faced malnutrition problem $18 \%$ faced dengue and rest of the $10 \%$ faced skin disease. 
Table 4: Access of the Food Items

\begin{tabular}{|l|c|c|}
\hline Name of the food item & Frequency & Percent \\
\hline 1Items & 22 & 22.0 \\
\hline 2 Items & 58 & 58.0 \\
\hline 3 Items & 12 & 12.0 \\
\hline 4 Items & 8 & 8.0 \\
\hline Total & 100 & 100.0 \\
\hline
\end{tabular}

Source: Field Survey, 2020.

22 children get one item per day for intake $58 \%$ of children gets 2 items, $12 \%$ gets 3 items and $8 \%$ get 4 items of food per day.

Table 5: Amount of Expand for Food (Monthly) in Slums Area

\begin{tabular}{|l|c|c|}
\hline Amount (monthly) & Frequency & Percent \\
\hline$<500$ & 22 & 22.0 \\
\hline $501-600$ & 46 & 46.0 \\
\hline $601-700$ & 18 & 18.0 \\
\hline $701-800$ & 8 & 8.0 \\
\hline $801-900$ & 4 & 4.0 \\
\hline 900 & 2 & 2.0 \\
\hline TOTAL & 100 & 100.0 \\
\hline
\end{tabular}

Source: Field Survey, 2020.

Table 5 shows that the majority, $46 \%$ of the respondent expend 501-600 BDT per month and lowest of the $2 \%$ of the respondent expands $>900$ BDT per month.

Figure 1: Main Course of the Children

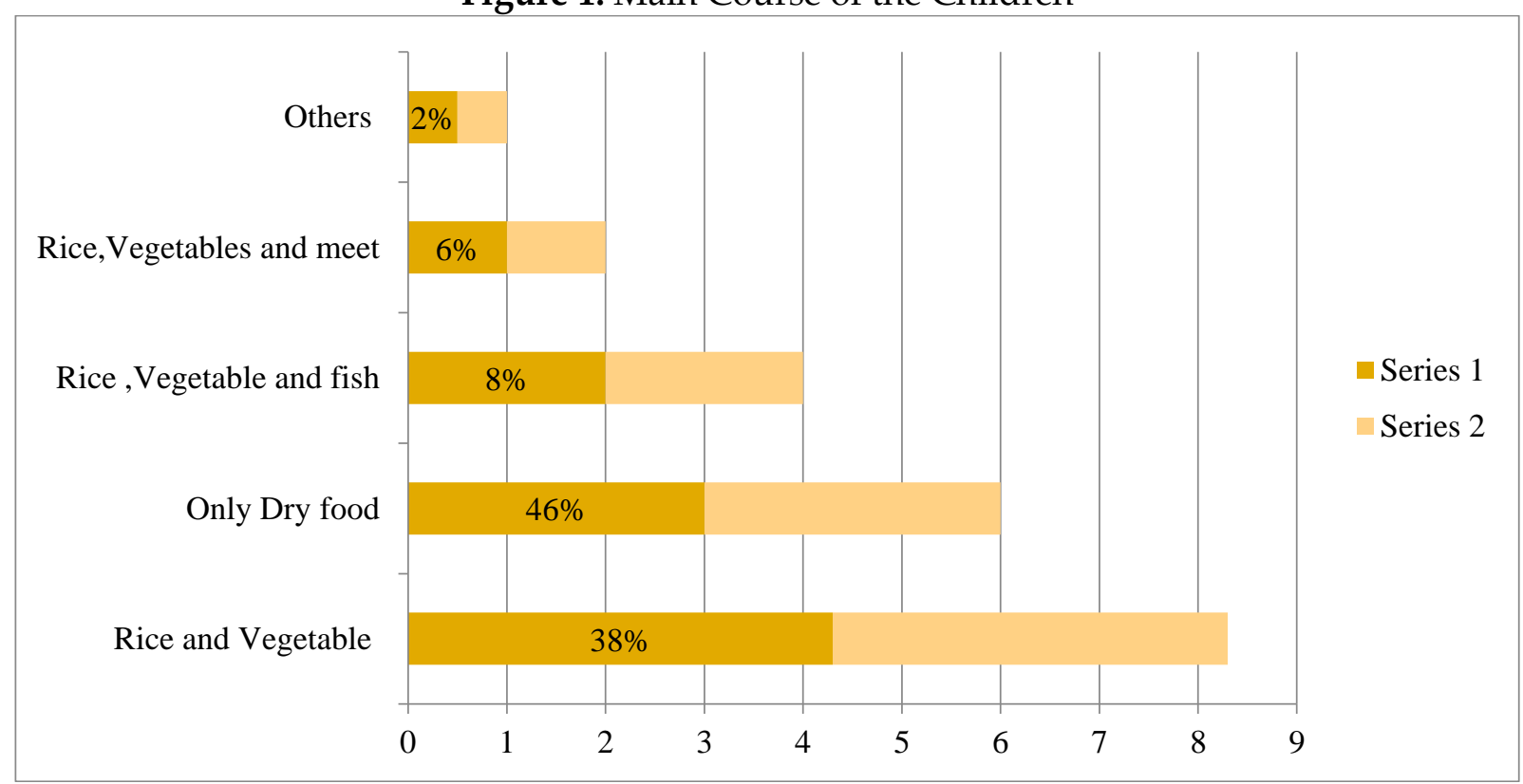

Source: Field Survey, 2020. 


\section{Findings \& Discussion}

\subsection{Trend and Pattern of Food Intake}

It reveals from the composition of the diet that the quality of the food basket is better for urban areas compared to rural areas.

The total intake was about $11 \%$ and $15 \%$ lower in rural and urban areas respectively; and for the national level, it was $12 \%$ lower than the minimum requirement There has been declining trend in the wheat consumption and increasing trend in the consumption of fruits, fish, and meat and eggs at the national level, which indicates the improvement of balance food intake in the national level.

It is also observed from there has been a declining trend of rice consumption for the urban areas during the last decade, which is contrast to the substantial increase in rice production in same years. Two reasons are assumed behind this: on the one hand, because of one hand, after the threshold level of income, when people can afford to have a diversified diet needed for balanced nutrition, the per capita consumption of staple food starts declining, but the poor are still spending their additional income on rice. On the other hand, it could be argued that the decline in rice consumption is a reflection of upward trend in the proportion of slum population due to rapid rural-urban migration resulted in higher pressure for expenditures which could reduce the purchasing power of staple food.

\subsection{Calorie and Protein Intake}

According to the Food and Agricultural Organization, the minimum dietary requirement in terms of energy is $1780 \mathrm{kcal} / \mathrm{capita} /$ day and the real availability is 2230 in Bangladesh. To meet the food security, at least $25 \%$ more food in terms of energy should be avail for the Bangladeshi people. So, the total energy requirement is the sum of minimum requirement and $25 \%$ of the minimum requirement which is $2225 \mathrm{kcal} /$ capita/day, is lower than total dietary consumption.

On the other hand, at least $12 \%$ energy should come from protein and $20 \%$ energy should come from fat. The share of energy from protein $(8.61 \%)$ and from fat $(10.90 \%)$ is lower than $12 \%$ and $20 \%$ respectively. Therefore, it may be concluded that Bangladesh is apparently just food secured in terms of total energy, but still it is not food secured in terms of share of the total energy coming from protein and fat.

\subsection{Changes in Nutritional Status}

Prevalence of malnutrition, particularly child malnutrition, though on a downward trend, is still at high level. About $40 \%$ of all children between 6 and 71 months are underweight or low weight for age, while more than $30 \%$ of them are stunted or low height for age (Table 6). Percentage of rural malnourished children was much higher than that of urban areas. Nearly $20 \%$ of the rural children are severely stunted and about $13 \%$ severely underweight. 
Table 6: Rural-urban Difference in Child (6-71 months) Malnutrition (percent), 2000

\begin{tabular}{|l|l|c|c|}
\hline Indicators & Area & Severe & Moderate \\
\hline Wasting & Rural & 1.0 & 10.9 \\
& Urban & 1.8 & 9.0 \\
& National & 1.1 & 10.6 \\
\hline Stunting & Rural & 19.7 & 31.0 \\
& Urban & 15.0 & 23.3 \\
& National & 19.0 & 29.8 \\
\hline Underweight & Rural & 13.2 & 39.6 \\
& Urban & 9.6 & 32.6 \\
& National & 12.6 & 38.5 \\
\hline
\end{tabular}

Source: Child Nutrition Survey of Bangladesh (2000).

The downward trends in stunting and underweight indicate that there has been considerable improvement in child malnutrition in Bangladesh. The prevalence of stunting, wasting and underweight has declined between 1992 and 2004 at a rate of 3.1, $2.6 \%$ and $2.7 \%$ respectively per annum. The trend of wasting indicates shortage of food while the faster decline of stunting and underweight indicate improved food security situation in recent years.

From the Table 7, it is observed that the prevalence of under nourishment has increased in 1995-1997 but decreased in 2000-2002 and it was the same in 2002-2004. The life expectancy has increased remarkably from 55 years in 1990-1992 to 63 years in 2004 . On the other hand, children mortality under five and infant mortality decreased from 144 and 96 in 1990-1992 to 77 and 56 per 1000 in 2004 respectively.

Table 7: Changes in Selected Food Security Indicators 1990-2002

\begin{tabular}{|l|c|c|c|c|}
\hline Indicators & $\mathbf{1 9 9 0 - 9 2}$ & $\mathbf{1 9 9 5 - 9 7}$ & $\mathbf{2 0 0 0 - 0 2}$ & $\mathbf{2 0 0 2 - 0 4}$ \\
\hline Prevalence of undernourishment (per cent) & 35 & 40 & 30 & 30 \\
\hline Number of undernourished (million) & 39.2 & 50.4 & 42.4 & 44.0 \\
\hline $\begin{array}{l}\text { Children mortality rate under five years (per } \\
1,000)\end{array}$ & 144 & 116 & 82 & $77+$ \\
\hline Infant mortality rate (per 1,000) & 96 & 75 & 54 & 56 \\
\hline Life expectancy (Years) & 55 & 60 & 62 & 63 \\
\hline
\end{tabular}

Food availability is the one of the conditions under the food security rules in the world food summit. The other two condition is access and utilization. These research focuses on the availability of food as an essential element of the concept of food security in slum are of the Khulna city. In addition to rice and wheat is the staple in Bangladesh. This study detail discussion about the production and availability issues of other major food commodities, such as potato, oilseeds, vegetables, fruits, fisheries and livestock products in the slums area of the Khulna city. Availability is a function of domestic production, imports, food aids, and security stock. Education greatly fall effect on survivor in life educational status of two major member of the family on side show that $14 \%$ male and $39 \%$ female were illiterate, $12 \%$ male and $21 \%$ female only can sign. Occupation level also shows economic status of the slum areas. Their economic status very worse at this time. $18 \%$ respondent were day labor $2 \%$ respondents had main income source is fishing and 
$26 \%$ of the respondent families had the income level of monthly 2001-3000 BDT. $6 \%$ of the respondent is the upper middle family income is more than 4000 BDT. Educational system of the Bangladesh is highly subsidized. The government of Bangladesh operates many schools in the primary, secondary, and higher secondary levels. It also subsidized part of the funding for many private schools. In the tertiary education sector, the government also funds more than 15 state universities through the University Grant Commission. Among all children's 54\% enrollment decrease and only $28 \%$ girls went to the school. And before $46 \%$ boys went to school and after $64 \%$ boys went to school. Usually, Bangladesh children faced many nutritional problems in mainly slum area. Many of children faced malnutrition problem. Majority of $46 \%$ of the respondents expend 501-600BDT per month. lowest of the $2 \%$ of the respondent expend more than 900 BDT per month, $26 \%$ respondent got food facility from government, $12 \%$ got food facility from NGO and $18 \%$ got food facility from voluntary group, 30\% foreign help and other $14 \%$ people got food facility from relatives. In addition, other different source promotes food security.

\section{Conclusion}

Overall, the situation development of slums area in Khulna city, more work to awareness about hygienic food. Natural disaster system has to challenging the slums area people. Mainly the water supply, sanitation, disease and shelter and food security. Many of the organization have carried out potential.

Majority of the respondents consider most of the student consider raw and halfcooked meat or raw unwashed vegetables and unhygienic practice of food handlers are the causes regarding to the food hygienic. This is because bacteria grown on the unhygienic handling food. However, majority of the respondents in the Khulna city slums area consider most of the stuffs wash hands using an anti-bacterial soap and single use paper to full fill the personal hygienic procedure. This show that hand hygienic is related to the food hygienic handling. To majority of the respondents do know the various bad effects caused by low level of hygienic on personal health including family children and their mother. Finally, yet importantly, the main effect influenced by the level of hygiene in the bacteria is the environment as well as.

\section{Conflicts of Interest}

The authors declare no conflicts of interests.

\section{Acknowledgements}

The authors would like to acknowledge the participants of Khulna city who participated to this work.

\section{About the Authors}

Taherun Nesa Subarna is a student majoring in Education management at, School of Teacher Education, Huzhou University. Her research interests include Social Science, 
Education, Psychology, Nutrition, Early Childhood Education, Child Autism, and Parent-Child Relation.

Nuruddin Ahmed Masud is a student majoring in Education Management, School of Teacher Education, Huzhou University. His research interests include Reading Education and Promotion, Philosophy of Education, Literature and Education, Sociology of Education and Knowledge, Social Psychology.

\section{References}

Abu Noman Mohammad Atahar Ali (2013). European Food and Feed Law Review. Vol. 8, No. 1, pp. 31-40 Published by: Lexxion Verlagsgesellschaft Gmbh.

Abbas Bhuiya and Kim Streatfield (1995). Journal of Diarrheal Diseases Research. Vol. 13, No. 2 (June 1995), pp. 106-112, Published by: Icddr, b

Abbas Bhuiya and Kim Streat (1991). Field Population Studies Vol. 45, No. 2, pp. 253-264 Published by: Taylor \& Francis, Ltd. on behalf of the Population Investigation Committee.

Álvarez Marín, M. (1987). Ways of life in poverty, adaptation or habit? INVI Magazine, $2(3), 18-35$.

Barnett, S., Azad, K., Barua, S., Mridha, M., Abrar, M., Rego, A., Khan, A., Flatman, D., \& Costello, A. (2006). Maternal and newborn-care practices during pregnancy, childbirth, and the postnatal period: a comparison in three rural districts in Bangladesh. Journal of health, population, and nutrition, 24(4), 394-402.

Dorosh, P., \& Haggblade, S. (1995). Filling the Gaps: Consolidating Evidence on the Design of Alternative Targeted Food Programmes in Bangladesh. The Bangladesh Development Studies, 23(3/4), 47-80. Retrieved March 26, 2021, from http://www.jstor.org/stable/40795536.

Held, I. M., \& Phillips, P. J. (1990). A Barotropic Model of the Interaction between the Hadley Cell and a Rossby Wave, Journal of Atmospheric Sciences, 47(7), 856-869. Retrieved Mar 26 , 2021, from https://journals.ametsoc.org/view/journals/atsc/47/7/1520$\underline{046919900470856 \text { abmoti } 20 \text { co 2.xml }}$

Hossain, M. (1990). Natural Calamities, Instability in Production and Food Policy in Bangladesh. The Bangladesh Development Studies, 18(4), 33-54. Retrieved March 26, 2021, from http://www.jstor.org/stable/40795387.

K. A. S. Murshid (1986). The Bangladesh Development Studies, 14(2). Retrieved March 26, 2021, from http://www.jstor.org/stable/40795243

Khan, S. I., Ahmed, A. K., Yunus, M., Rahman, M., Hore, S. K., Vahter, M., \& Wahed, M. A. (2010). Arsenic and cadmium in food-chain in Bangladesh--an exploratory study. Journal of health, population, and nutrition, 28(6), 578-584. https://doi.org/10.3329/jhpn.v28i6.6606

Mahtab Fasihuddin, and Kamal Saleh Mustafa (1993). Green House Effect in Bangladesh. Dhaka: Prokaushali Sangshad. 
M. Mizanur Rahman Miah (1993). International Journal of Sociology of the Family Vol. 23, No. 2, pp. 21-34. Published by: International Journals

Md Mosfequr Rahman (2015). International Perspectives on Sexual and Reproductive Health Vol. 41, No. 2.

Margot Wilson (1999). Journal of Comparative Family Studies Vol. 30, pp. 687-702 Published by: Dr. George Kurian.

Mostafa, M., Hoque, M. S., Nahar, K., \& Evans, G. (2004). Maternal induced haploids in rye (Secale cereale L.). Euphytica, 72, 213-217.

Omar Haider Chowdhury and S. R. Osmani (2010). The Bangladesh Development Studies Vol. 33, No. 1/2, the Human Rights Approach to Development, pp. 205-273 Published by: Bangladesh Institute of Development Studies

Pradip K. Muhuri (1995). Population and Development Review Vol. 21, No. 4, pp. 813-834 Published by: Population Council.

Razzaque, Abdur \& Khondker, Bazlul H. \& Mujeri, Mustafa K. (1997). Elasticity Estimates by Occupational Groups in Bangladesh: An Application of Food Characteristics Demand System, Bangladesh Development Studies, Bangladesh Institute of Development Studies (BIDS), vol. 25(3-4), pages 1-42, Sept-Dec.

Rushad Faridi and Syed Naimul Wadood (2010). The Bangladesh Development Studies Vol. 33, No. 3, pp. 97-111 Published by: Bangladesh Institute of Development Studies.

Shahabuddin, Q. (2010). The Right to Food: Bangladesh Perspectives. The Bangladesh Development Studies, 33(1/2), 91-138. Retrieved March 26, 2021, from http://www.jstor.org/stable/23339886

Sharifa Begum (1983). The Bangladesh Development Studies Vol. 11, No. 4, pp. 17-59 Published by: Bangladesh Institute of Development Studies

Talukder, R. (2005). Food Security, Self-sufficiency and Nutrition Gap in Bangladesh. The Bangladesh Development Studies, 31(3/4), 35-62. Retrieved March 26, 2021, from http://www.jstor.org/stable/40795714. 
Taherun Nesa Subarna, Nuruddin Ahmed Masud

SOCIAL AWARENESS ABOUT HYGENIC FOOD FOR MOTHERS \& THEIR CHILDREN

Creative Commons licensing terms

Author(s) will retain the copyright of their published articles agreeing that a Creative Commons Attribution 4.0 International License (CC BY 4.0) terms will be applied to their work. Under the terms of this license, no permission is required from the author(s) or publisher for members of the community to copy, distribute, transmit or adapt the article content, providing a proper, prominent and unambiguous attribution to the authors in a manner that makes clear that the materials are being reused under permission of a Creative Commons License. Views, opinions and conclusions expressed in this research article are views, opinions and conclusions of the author(s). Open Access Publishing Group and European Journal of Public Health Studies shall not be responsible or answerable for any loss, damage or liability caused in relation to/arising out of conflicts of interest, copyright violations and inappropriate or inaccurate use of any kind content related or integrated into the research work. All the published works are meeting the Open Access Publishing requirements and can be freely accessed, shared, modified, distributed and used in educational, commercial and non-commercial purposes under a Creative Commons Attribution 4.0 International License (CC BY 4.0). 